\title{
Cultural Relations and Political Considerations: The British Council in Eastern Europe during the 1980s
}

\section{Dr. Malika SAHEL}

Ecole Normale Supérieure/Bouzaréah (E.N.S.B), Department of English Algiers/Algeria

\begin{abstract}
Established between the Two World Wars in 1934, the British Council was charged to undertake Britain's cultural relations with other countries. However, its direct involvement and adjustment to Britain's sudden political decisions, on the international scene, is an indication on the inter-relationship between the British cultural section and the other sections of British foreign policy despite the structural separation of the British Council from British Embassies abroad and the autonomous status this cultural agency was believed to enjoy.
\end{abstract}

Keywords: Cultural Relations - Political Considerations - British Council - Eastern Europe - Cultural Diplomacy.

\section{Introduction}

Ideology has played an increasingly important role in international relations as an excuse and justification for action. For instance by the end of the 1930's, the Allies went to war in defence of western civilization and afterwards divided into ideologically separate blocs. Between the two worlds wars every major European power embarked on a programme of national advertisement. France, Germany and Italy simply multiplied the activities of "cultural bodies" they established in the $19^{\text {th }}$ century. In 1925, the Soviet Union founded the "All Union Society for Cultural Relations with Foreign Countries" (VOKS) and in 1934, Britain established the British Committee which became the British Council to consolidate her world position and protect her interests.

The object of the present paper is to consider some of the main uses of cultural relations then to examine the British Council relations with Eastern Europe during the 1980's as the British foreign policy under Margaret Thatcher moved eastwards where new opportunities were offered. To what extent could the British Council cultivate a good image of capitalist Britain in communist Eastern Europe?

Before considering the uses of cultural relations, it is worth defining cultural relations and referring to cultural diplomacy to clarify the difference between the two concepts.

\section{I- Cultural Relations/Cultural Diplomacy:}

Cultural relations consist in cultivating cooperation between educational and cultural institutions and people to link different communities, through culture, so that communication and understanding in cultural fields, artistic, intellectual and social are achieved. The purpose is to reach and maintain understanding and promote cooperation between different nations for their mutual advantage. Unlike cultural diplomacy which presents a beautified picture of each country, cultural relations far from being selective - try to give a truthful image of a given country's culture.

Cultural relations are basically different from cultural diplomacy though they are very often thought to be "synonymous". 1 Indeed, the sphere of cultural relations is wider : they operate beyond the performance of governments and their bodies since they can be initiated and supervised by public institutions as well as by private ones.

Cultural relations do not seem to serve time-bound objectives. Their aim is to promote an enduring understanding by trying to dispel misunderstanding or prejudices vis-à-vis the host countries through favourable images or manifestations. These are viewed by governments as being free from political control. Indeed, when diplomatic relations between two countries are broken off and hostility between their governments grows, cultural relations can continue between their peoples -

1 J. Mitchell, International Cultural Relations, London : Allen \& Unwin, 1986, p. 2. 
through non-governmental bodies. ${ }^{1}$ For instance, in the 1960's Algeria broke off her diplomacy relations with Britain. Yet, the British Council - a cultural body - carried on its activities in Algeria.

Cultural relations have a broader range than cultural diplomacy though they involve the methods of the latter. Their budget is made out of government grants as well as out of gains and revenues from international sources. In fact, it is only in practice that cultural relations appear to be different from cultural diplomacy. Both resort to the use of culture to establish interaction between different nations. But, whereas the hope of the first one is not necessarily to reach unilateral benefits, the second one's aim is characterized by presenting culture to impress other countries in order to meet certain diplomatic ends.

Thus, it is the kind of use of culture that makes a clear cut difference between cultural relations and cultural diplomacy. For instance, a government can shift from cultural relations by using cultural diplomacy for the sake of direct political and economic purposes.

\section{II- The Main Uses of Cultural Relations:}

Governments' main arguments for financing cultural relations comprise 'peace', 'international understanding', 'commerce' and 'conventional diplomacy'. ${ }^{2}$ These, in fact, embody the most important uses of cultural relations.

\section{a- Cultural Relations and Peace:}

Peace has always been regarded as a blessing and conversely, war as something that causes suffering, a scourge. Therefore, cultural relations may be reviewed as a means of maintaining peace among nations. Yet, although the latter's general conviction that war should be avoided, only few efforts to advance peace are made. Understandably, peace is mostly sought by ordinary citizens. For instance, during the late 1940's, the World Peace Council allegedly gathered 550 million signatures. ${ }^{3}$ Probably, most of those who signed wanted and wished peace founded on mutual respect for distinct political systems. The world is always in need of a strong factor which would provide a favourable climate for peace between different countries. But few universities in the world include departments of peace studies and peace is rarely a school subject. ${ }^{4}$

The cultural sphere can be the appropriate one to promote peace. Indeed, cultural ties between nations remain the most crucial links in international relations for their immeasurable benefits. How can cultural relations be called upon to promote peace ? By their national focus on specific activities to introduce people to one other, by the transfer of experience and profitable skills and by presenting the value of peaceful activities, cultural relations provide a favourable atmosphere which may allow the flourishing of peace.

Thus, the consequences of the Second World War led European countries to fervently advocate peace. In this context, it was stated that "the Germans turned to cultural communications after World War II as a necessary part of recreating the national image after the Nazi debacle". In 1984, for example, the State Minister of Federal Germany confirmed the German decision to serve peace. Keeping in mind the German feeling of the guilt towards the world as suggested in the above cited quotation, the German foreign cultural policy was expected to preserve peace. Indeed, the German approach was expressed mainly through the manifested cooperation in the cultural field. ${ }^{6}$ In fact, Germany gave a special importance to peace in her cultural relations, probably also for other reasons than guilt. Another example lies in the United States of America. When urging the Americans to adopt the People to People Programme in 1956, Eisenhower stated that the way to exploit the general desire for peace was to convince ordinary people "to lead their governments - if necessary to evade governments". ${ }^{7}$ Individuals from all over the world with whom ideas could be shared represented a force. Indeed, by promoting a kind of warmth between people from different countries, the feeling of jeopardy could be reduced, through

\footnotetext{
1 lbid, p. 35.

2 lbid, p. 13.

${ }^{3}$ Idem.

${ }^{4}$ Idem.

${ }^{5}$ T. L. Deibel, W. R. Roberts, Culture and Information : Two Foreign Policy Functions, London : Sage, 1976, p. 60.

${ }^{6}$ German Federal Foreign Office, Foreign Cultural Policy : Comments of the Government of the Federal Republic of Germany on the

Report on Foreign Cultural Policy, Bonn: German Federal Foreign Office, 1978, p. 7.

7 P. H. Coombs, The Fourth Dimension of Foreign Policy : Educational and Cultural Affairs, New York : Harper and Row, 1964, p. 42.
} 
cultural relations because the latter - as stated by the Italian writer W. R. Pendergast "constitute as alternative channel of information and impressions and relieve mass insecurities by symbols of hope and understanding".1

Therefore, the hope has been expressed in various instances that peace can be served and achieved through cultural relations, as means of promoting understanding.

\section{b- Cultural Relations and International Understanding:}

Understanding is, indeed, a prominent objective of cultural relations while prejudice stands as one of the obstacles. Nothing is more efficient than providing contrary evidence to succeed in fighting stereotypes. cultural programmes are, as already suggested meant to give a favourable image, to prevent unwelcome reactions or interpretations, particularly those supported by ideologies, since these may be viewed as "representing the greatest obstacle to the sincere combatting of stereotypes. Ideologies are in general nothing but prejudices refined a a system for influence and ultimately for domination". ${ }^{2}$ For example, at a universal or multilateral level, the material used in education of the young is the first thing to be checked by certain international organizations so that stepping stones - stereotypes - can be greatly reduced. This is part of the efforts displayed at multilateral level in Brunswick by the Georg Eckert Institute - whose work is connected to UNESCO and the Council of Europe - which aims at rectifying and improving knowledge and understanding between nations. On the other hand, the International Society for Educational Information - located in Japan - specifically checks foreign text-books about Japan.

Moreover, the direct bilateral promotion of cultural information and technical activities allow different peoples to know eah other better. Cultural bodies promote cultural programmes that assist and foster positive understanding. Among other devices used by cultural agencies in the sending of people from their country to serve abroad and the bringing of foreigners to their own soil for studies or training. Indeed, "people exchange" between different countries remains the best means of accelerating understanding between individuals belonging to different cultures. This approach is practical because people move in both directions to see for themselves what each nation is and what it has to offer in terms of knowledge and scientific achievement especially when they cooperate and work together, since doing things together allows people to communicate more to promote favourable mutual images.

It is for such a reason in part, that most of the cultural agencies' funds are spent on sending teachers, lecturers and advisers overseas to offer their expertise to foreign countries and on bringing people on their own soil for professional visits, training and studies. By cultivating friendship between people belonging to different cultures, a bridge is thus built, through which other kinds of general ties can spring, commercial ones in particular.

\section{b- Cultural Relations as a Support for Conventional Diplomacy:}

During the $20^{\text {th }}$ century, cultural relations have acquired a significant role in international affairs. ${ }^{3}$ Many countries have recognized them as the third dimension which accompanies politics and trade in relation between states. In 1964, Senator Fulbright, after whom one of the most imaginative exchange schemes is named, stated in his Foreword to The Fourth Dimension of Foreign Policy that "[c]ultural relations have become an intrinsic part of the way governments and nations relate to one another and of the way institutions and peoples form an understanding of one another across frontiers". (Coombs, 164) In 1966, cultural relations were referred to, for the first time, by the term 'third pillar of foreign policy' by the then German Foreign Minister, Willy Brandt. ${ }^{4}$ Besides, Senator Fulbright further explained in his Foreword to The Fourth Dimension of Foreign Policy that,

\footnotetext{
1 W. R. Pendergast, "The political Use of Cultural Relations", translated by J. Mitchell, II Politico : Rivista di Scienze Politiche, Vol. 38, $\mathrm{n}^{\circ}$ 4 ,

1973 , p. 696

2 Quoted in J. Mitchell, op.cit, p. 18.

${ }^{3}$ P. H. Coombs, op. cit, p. ix.

4 J. Mitchell, International Cultural Relations, London : Allen \& Unwin, 1986, p. 1.

- For some American writers cultural relations come in the fourth position : after politics, trade and defence. Coombs seems to be one of

these at the title of his book suggests.
} 
[f]oreign policy cannot be based on military posture and diplomatic activities alone in today's world. The shape of the world a generation from now will be influenced far more by how well we communicate the values of our society to others that by our military or diplomatic superiority. (Coombs, 1964, p. ix)

The British had implicitly expressed the same point of view in a Foreign Office report as early as 1938. As this suggested :

Of the three elements which go to make up British influence - political, economic and culture - the first two had long been recognized as fundamental and both our political and our commercial influence had been carefully promoted and protected. The third element, our cultural influence, was regarded either as something vaguely creditable but of little practical use or alternatively considerations that it ought never to be degraded to political ends. (Foreign Office, 1938, p. 7)

Indeed, organized activities - such as manifestations of culture, art exhibitions, musical or theatrical performances - by cultural agencies can produce a direct positive impact or work indirectly through the reputation generated by more routine operations - as is the case with languages classes and library services for example. Though the latter are realized at an informal level, they serve conventional diplomacy and bilateral relations in general.

Although the cultural section is small within a country's embassy, its efficiency greatly affects the other sections which depend on the dynamism of cultural diplomacy. It happens that cultural relations manage to achieve results in the breaking down of barriers between countries. As a good example, one can cite Britain's support for the Bolivar bicentenary of 1983 in Venezuela which was effectively stage-managed since it was meant to re-establish a positive impression after the tension which followed the Falklands Campaign of 1982 and indeed, as suggested by J. Mitchell :

The United Kingdom's [cultural] support for the Bolivar bicentenary of 1983 in Venezuela did much to restore friendly feeling after the strain that followed the Falklands campaign of the previous year. ${ }^{1}$

Among such significant cultural activities, the organization of sport events between teams belonging to different cultures can be cited as an effective means of creating positive impressions among them, a fact that contributes to the promotion of cultural relations which in their turn can support Conventional Diplomacy. Indeed, sport in its non-commercial form, can be viewed as coming within the wide definition of cultural relations. In this context, one can recall one of the greatest breakthroughs in history, the Ping-Pong diplomacy of 1971. An American table-tennis team on an Asian tour coped well with a competing team from China, which had invited it for a visit. ${ }^{2}$ Chou En-lai, who received the American guests, made a speech in terms of friendship going beyond Ping-Pong. This, in fact, was followed by Henry Kissinger's exploratory visit to Peking and subsequently by President Nixon's. Consequently, a positive alteration was witnessed in the relations between the USA and China. ${ }^{3}$ Kissinger suggestively pointed out that "[one] of the most remarkable gifts of the Chinese is to make the meticulously planned appear spontaneous", ${ }^{4}$ a comment which covers more than practical preparations. The same thing can be said about the English Queen's speech opening the Commonwealth games.

\footnotetext{
1 J. Mitchell, op.cit, p. 16.

2 Idem.

3 Idem.

${ }^{4}$ Idem.
} 
As regards France, this country has always been particularly conscious of the diplomatic advantages that could be drawn from the spread and promotion of its own culture. Accordingly, for a long time, her ambassadors were taught before leaving France, "Faites aimer la France" - "Make them love France". ${ }^{1}$ They were asked to use their talents to acquaint peoples and make them aware of France's potentialities and grandeur.

\section{d- Cultural Relations as a Bridge for Commerce:}

European countries in general and Britain in particular could not however ignore the commercial benefits that could result from cultural expansion. Indeed, commercial contracts have been shown to be likely to be derived from cultural relations between two given countries. Indeed, if we know someone else's language and literature, and appreciate his country and its art, we are likely, for instance, to prefer buying goods from his country rather than from a less well known source. ${ }^{2}$

Britain can be viewed as a country where, in its cultural relations with other nations, the commercial component prevails in such a way that the British Council sometimes appears to act more like a commercial agency than as a cultural body when what it does extends beyond the cultural field proper to encompass the promotion of book-export, art, and the English language for example. ${ }^{3}$ Indeed, Britain has been persuaded that the 'British Council' is the qualified organization which really proves and reinforces these advantages concretely by the diversity and the flexibility this cultural body's work has known.

As a matter of fact several British official reports, during the fifties and sixties, successively focused on and emphasized the trade gains to be derived from cultural work. In 1954, Lord Drogheda said : "Although the method all through is strictly non-political, at the end of process a considerable political and commercial benefit is likely to be received". ${ }^{4}$ This fact has been relativized by British officials as being part of a general trend in international cultural activity : "Many nations", it has been noted, "undertake cultural programs precisely for the result they are expected to produce. In several cases these results are highly specific: The British hope to increase sales abroad, ...". ${ }^{5}$

Moreover, the Chairman of the Review Committee on Overseas Representation, Sir Duncan went so far as to say, in 1969

As Britain turns from politico-military relations towards other ways of making her presence known to other countries, especially outside Western Europe and the North Atlantic area, it will be necessary to develop more fully the other forms of contact with governments and peoples.... The British Council (and BBC) will enable Britain to make her as a future trading and cultural partner of major importance, rather than in the role of a leading world power. ${ }^{6}$

As is apparent in the above quotations the British commercial spirit has not been absent from the encouragement of the cultural work which British services have undertaken abroad, particularly in terms of "people exchange".

On the other hand, while French cultural relations, for instance, have been led independently from economic and information services activities, France has not disregarded cultural relations' commercial benefits. ${ }^{7}$ As early as 1919 , the French rapporteur for the Commission on the budget of the Ministry of Foreign Affairs, Mr. Raiberti, stated that "intellectual and

\footnotetext{
${ }^{1}$ H. Arnold, Foreign Cultural Policy : A Survey From a German Point of View, London : Oswald Wolff, 1979, p. 21.

${ }^{2}$ A. Parson, "Vultures and Philistines : British Attitude to Culture and Cultural Diplomacy", London : British Council, 1984, p. 11.

3 J. Mitchell, op.cit, p. 21.

${ }^{4}$ Lord Drogheda (Chairman), "Summary of the Report of the Independent Committee of Enquiry into Overseas Information

Services",

London: HMSO, 1954, p. 33.

5 T. L. Deibel, W. R. Roberts, op.cit.

${ }^{6}$ Sir Duncan (Chairman), "Report of the Review Committee on Overseas Representation 1968-1969", London : HMSO, 1969), p. 106.

${ }^{7}$ P. H. Coombs, op. cit, p. 80.
} 
moral expansion was the best way to prepare for economic expansion"1 In other words, better cultural relations with other countries lead to better economic links. The French authorities were not the only ones, in fact, to acknowledge this link explicitly. This statement echoes the substance of a 1964 article on British Council policy entitled "British Council Survey and Annual Review". ${ }^{2}$ In this article, this agency is presented as "an organization whose world-wide activities [have been] promoting good will for Britain and paving the way for British overseas trade in the post-war era". ${ }^{3}$

Indeed, cultural agencies have been very often asked to operate for foreign countries as intermediaries expected to find and select Technical Advisers, Professors and Lecturers in subjects encompassing a wide field of economic life, such as Industrial Chemistry, Metallurgy, in addition to traditional Naval Construction, as well as academic subjects such as Astronomy, Cyneachology, Geology, Physics, Mathematics and Organic Chemistry, for instance. From all these subjects trade relations might indirectly be positively affected.

Thus, cultural activities or programmes can create more constructive basis for political and economic relations as well as they could serve as a basis for the leading of one's foreign policy.

\section{III- The British Council in Eastern Europe: A Change in Focus}

The British Council had naturally established offices not only in Commonwealth countries, but in countries which do not belong to the Third World being aware that some of these - if not all - can represent some importance - either political or economic - to Britain. A striking example during the 1980's onwards has been the British Council relations with the Soviet bloc countries.

Since the first seeds of perestroika and glasnost started - in 1985 - showing their consequences in Eastern bloc as we knew it, an automatic change in the whole focus of both the British Council and all the other related institutions including the financial, the economic and the industrial institutions has been noticeable ; these institutions have since been looking Eastwards rather than Southwards - rather than toward North Africa for example, where people were ready to pay high sums of money for British Council services.

This policy, in fact, was in line with Thatcher's move toward the East. ${ }^{4}$ Moreover, the new impetus given by a leader like Gorbachev and his Foreign Minister Shevardnadze to East-West dealings, particularly in matters of arms control paved the way for the new British-Soviet relations. ${ }^{5}$ In July 1986, Mr. Shevardnadze's visit to Britain meant that both the Soviet Union and Britain wanted to put an end to their previous problems and the indifference that had colored their relations before. It also announced Britain as a channel between Moscow and Washington. ${ }^{6}$

In addition to the specifically Anglo-Soviet agreements - for example the Economic and Industrial Cooperation Programme for 1986-90, signed in 1986 - the first half of 1987 witnessed a series of visits between leaders from London and Moscow. ${ }^{7}$ In January, after six years' continuous activity, the Soviet blockage of BBC Russian-language broadcasts knew an end. In February, a new long-term finance and credit agreement was worked out in order to stimulate British export of capital goods. ${ }^{8}$ This month also saw rather investigative talks on the frustration of world terrorism. ${ }^{9}$

Yet, Thatcher's official visit to Moscow from 28 March to 2 April stood as the most important one ; the summit engaged with Gorbachev was marked by 1 hours of talks which mostly covered East-West arms control issues. As a result, the two leaders agreed on the setting up of the London-Moscow "hot line", on more diplomatic exchanges, on cooperation in space, as well as on educational and cultural exchange. ${ }^{10}$

${ }^{1}$ Quoted from R. E. Mc Murry, M. Lee, The Cultural Approach : Another Way in International Relations, Port Washington, London : Kennikat Press, 1972, p. 16.

${ }^{2}$ This article was published in the War Time Trading Bulletin in 1944.

${ }^{3}$ R. E. Mc Murry, M. Lee, op. cit, p. 162.

4 P. Byrd, British Foreign Policy Under Thatcher, America : Philip Allan Publishers, 1988, p. 72.

${ }^{5}$ Idem.

${ }^{6}$ Idem.

7 Idem.

8 Idem.

${ }^{9}$ Idem.

10 Idem. 
Accordingly, the British Council multiplied its efforts and extended its work to cover not only the ex-USSR but previously inaccessible areas in this part of the world. Indeed, to put forward mixed economics, in 1989, the British Council's fellowship programmes in USSR, Poland and Hungary covered business studies, law, economics and finance. ${ }^{1}$ Consequently, an important part of the Council's increased government grant designated for Eastern Europe during the period 1989-90 was significantly spent on management training in the ex-Soviet Union. The aim behind was meet the needs of the new commercial and other managers in the countries of Eastern Europe. ${ }^{2}$ The Council also opened 13 new teachers' resource centres throughout Eastern and Central Europe and the countries of the former Soviet Union (in 1993-94), and was to assist more than 27,000 English language teachers in the state system. ${ }^{3}$ In addition to its supply of 13 countries in the area with training and professional advice, the British Council extended its work to Georgia, Belarus, Kazakhstan and Uzbekistan from its offices in Russia and Turkey. ${ }^{4}$ By the end of the 1980's, looking eastwards became a matter of scrutinizing the East rather than just looking towards it. ${ }^{5}$

In fact, the political shift towards the East witnessed in British Foreign policy at that time, compromised the British Council's activities in other parts of the world because the latter had to follow its government's new priorities even though its funds were not increased. Yet, in North Africa for example, thousands of people kept hoping for such cooperativeness despite the high fees the British Council used to impose in French-speaking countries. In fact, during that period (the second half of the 1980's), the Council closed down quite a few of its offices in Africa - for example in Algeria - basically in countries which they apparently were thought to have become of less importance to Britain than the new ones. Apparently, therefore, the British Council had to look twice at its expenses and this must have consisted in closing down offices in parts of the world and opening up others in other areas which it was thought would be more lucrative - in the political sense rather than in the economic sense - though in the long-term of course politics and economics were both to have importance.

\section{Conclusion:}

The British Council's well known large establishment in Commonwealth countries - where unlimited British political, economic and cultural interests lie - and the sudden dynamism which its activities knew in Eastern Europe, during the second half of the 1980's in particular, as a consequence of Britain's new attunement to the East, was a remarkable reflection of the linkage between the political and cultural spheres in Britain's Foreign policy. Thus, the British Council cultural work could not avoid the pressure of political considerations to maintain a significant distance from cultural diplomacy.

\section{References:}

[1] Arnold H., Foreign Cultural Policy : A Survey From a German Point of View, London : Oswald Wolff, 1979.

[2] Byrd P., British Foreign Policy Under Thatcher, America : Philip Allan Publishers, 1988.

[3] Coombs P. H., The Fourth Dimension of Foreign Policy : Educational and Cultural Affairs, New York : Harper and Row, 1964.

[4] Deibel T. L., Roberts W. R., Culture and Information : Two Foreign Policy Functions, London : Sage, 1976.

[5] German Federal Foreign Office, Foreign Cultural Policy : Comments of the Government of the Federal Republic of Germany on the Report on Foreign Cultural Policy, Bonn: German Federal Foreign Office, 1978.

[6] Lord Drogheda (Chairman), "Summary of the Report of the Independent Committee of Enquiry into Overseas Information Services", London : HMSO, 1954.

[7] Mc Murry E. R., Lee M., The Cultural Approach : Another Way in International Relations, Port Washington, London : Kennikat Press, 1972.

[8] Mitchell J., International Cultural Relations, London : Allen \& Unwin, 1986.

[9] Parson A., "Vultures and Philistines : British Attitude to Culture and Cultural Diplomacy", London : British Council, 1984.

\footnotetext{
1 The British Council, "The British Council Annual Report and Accounts 1988-89", London : The British Council, 1989, p. 28.

2 Idem.

The British Government wanted to contribute to the rebuilding of eastern countries' economies and the British Council helped it.

3 The British Council, "The British Council Annual Report and Accounts 1993-94", London : The British Council, 1994 , p. 4.

4 Idem.

${ }^{5}$ Personal interview, Moroccan Embassy in London, (August, 1995).
} 
[10] Pendergast W. R., "The political Use of Cultural Relations", translated by J. Mitchell, II Politico : Rivista di Scienze Politiche, Vol. 38, nº 4, 1973.

[11] Personal interview, Moroccan Embassy in London, (August, 1995).

[12] Sir Duncan (Chairman), "Report of the Review Committee on Overseas Representation 1968-1969", London: HMSO, 1969).

[13] The British Council, "The British Council Annual Report and Accounts 1988-89", London : The British Council, 1989.

[14] The British Council, "The British Council Annual Report and Accounts 1993-94", London : The British Council, 1994. 